\title{
Influence of section and moisture content on the tensile strength parallel to fibers of bamboo culms woody material ${ }^{1}$
}

\author{
Luiz Henrique Marra da Silva Ribeiro², Lucas Misael de Aguiar ${ }^{3}$, \\ Ewerton Augusto de Souza Nogueira ${ }^{4}$, José Felipe Dias ${ }^{4}$, Luiz Alberto Beijo ${ }^{2}$
}

\section{ABSTRACT}

Bamboo is an abundant plant in tropical regions, which can be used as a nonconventional structural material; however, there is a high variability in its mechanical properties. This study aimed to evaluate the influence of the moisture content and of the sections (with and without node) on the tensile strength parallel to the culm fibers of three bamboo species (Dendrocalamus asper, Phyllostachys pubescens and Phyllostachys aurea), aiming at their use for structural purposes. For each moisture condition (ambient, saturated in water, oven dried and control), a completely randomized design, following a $3 \times 2$ factorial scheme, was used. Phyllostachys pubescens exhibited a higher tensile strength parallel to the fibers than the other species. In general, the node affected negatively the tensile strength parallel to the fibers for all analyzed conditions, while the moisture content did not show a significant influence, although the descriptive analysis exhibited its influence on the dimensional variations and water absorption.

KEYWORDS: Dendrocalamus asper, Phyllostachys aurea, Phyllostachys pubescens.

\section{INTRODUCTION}

Bamboo fibers can be used in structural areas, with or without the reinforcement of matrix types such as soil and cement composite (Ghavami 1995 and 2005). In the industrialized era, the factors that influence the materials choice are basically price and application. Nevertheless, due to the educational system designed for conventional materials, developing countries do not use the available material, because they lack technical information about it (Ghavami 1995 and 2005, Beraldo 2003).

\section{RESUMO}

Influência da seção e teor de umidade na resistência à tração paralela a fibras de material lenhoso de colmos de bambu

O bambu é uma planta abundante em regiões tropicais, a qual pode ser utilizada como material estrutural não convencional; contudo, há alta variabilidade em suas propriedades mecânicas. Objetivou-se verificar a influência do teor de umidade e das seções (com e sem nó) na resistência à tração paralela a fibras dos colmos de três espécies de bambu (Dendrocalamus asper, Phyllostachys pubescens e Phyllostachys aurea), visando a aplicações estruturais. Para cada condição de umidade (ambiente, saturação em água, secagem em forno e controle), foi utilizado delineamento experimental inteiramente casualizado, em esquema fatorial 3 x 2. Phyllostachys pubescens apresentou maior resistência à tração paralela do que as demais espécies. Em geral, o nó afetou negativamente a resistência à tração paralela para todas as condições, enquanto o teor de umidade não apresentou influência significativa, embora a análise descritiva tenha evidenciado sua influência nas variações dimensionais e na absorção de água.

PALAVRAS-CHAVE: Dendrocalamus asper, Phyllostachys aurea, Phyllostachys pubescens.

There are several advantages in using bamboo as a material for structural purposes: the maximum growth of a culm in an adult vegetative clump is achieved on a short period of time, usually between one and six months (Beraldo 2003, Wakchaure \& Kute 2012); the maximum mechanical strength is reached in a few years, commonly between three and six years; it is highly available in tropical and subtropical regions (Beraldo 2003, Ghavami 2005, Wakchaure \& Kute 2012); the energy required to obtain bamboo, by volume, is much smaller than for steel (Beraldo 2003, Ghavami 2005); the specific resistance, which is the material tensile strength

1. Received: Jun. 19, 2018. Accepted: Sep. 27, 2018. Published: Feb. 07, 2019. DOI: 10.1590/1983-40632019v4953562.

2. Universidade Federal de Alfenas, Alfenas, MG, Brasil. E-mail/ORCID: luiz.marra@outlook.com/0000-0002-5929-1856, prof.beijo@gmail.com/0000-0002-3286-5602.

3. Universidade de Franca, Franca, SP, Brasil. E-mail/ORCID: lucas_misael@yahoo.com.br/0000-0003-1960-3779.

4. Universidade de Itaúna, Itaúna, MG, Brasil.E-mail/ORCID: labmetal@uit.br/0000-0002-1848-749X, josefelipedias@gmail.com/0000-0001-9987-2180. 
divided by the material density, of bamboo can be six times higher than the steel one (Ghavami 1995, 2005 and 2008, Beraldo 2003), and it also takes advantage over steel when considering the ratio between mechanical strength and cost (Mahzuz et al. 2013).

Although bamboo has, in general, a mechanical strength lower than steel, its tensile strength parallel to the fibers may exceed $350 \mathrm{MPa}$ (Ghavami 1995 and 2005, Beraldo 2003, Wakchaure \& Kute 2012, Mahzuz et al. 2013).

For structural designs using conventional materials, it is necessary to know the tensile strength, yield strength and material dimensions (Hibbeler 2010). In many cases, it is valid because the variability of the mechanical strength is relatively low, so that it is absorbed by the use of a safety factor.

Bamboo culms present a high variability of properties for the same species, and some characteristics should be controlled, such as their age. The position of the culm sections in the plant should be also controlled, since the mechanical properties and the moisture content vary greatly for different ages and heights of the bamboo culm section (Wakchaure \& Kute 2012, Carrasco et al. 2017). Moreover, according to Liese (1992), the bamboo species selection should be related to its application, because the mechanical properties vary considerably for different species (Chung \& Yu 2002). Studies on bamboo as a structural material are limited (Liese 1992, Ghavami 1995, 2005 and 2008), and methodological differences in the process of obtaining properties are common (Beraldo 2003).

In general, the moisture content interferes in the mechanical properties of wood (Rapp \& Sailer 2000). For bamboo, the moisture content also influences the mechanical properties, and the moisture content, in turn, varies for different heights of the bamboo culm in the plant, even just after harvesting until after the drying period (Wakchaure \& Kute 2012). According to Beraldo (2003), the dimensional stability depends on the moisture content of the bamboo culm, so the mechanical properties vary with the height of the studied section of the bamboo culm.

The high presence of starch and protein in bamboo culms are conducive of degradation by certain fungi species, what can reduce the quality and strength of the bamboo culm (Xu et al. 2013). According to Beraldo (2003), a recently harvested bamboo generally presents the moisture content of
$80 \%$, and after four months in ambient conditions, it usually has a moisture content between $10 \%$ and $15 \%$. This range must be kept in order to optimize the mechanical strength. A moisture content higher than this range may lead to fungi attack, and the service life of the material is compromised, because there is a high chance of presenting mold, which can degrade the material (Beraldo 2003, Wakchaure \& Kute 2012). Therefore, as the moisture content of the bamboo culm is affected by the environment, and the moisture content can influence its service life (Beraldo 2003, Ghavami 2005, Wakchaure \& Kute 2012), in order to protect the bamboo culms in structural projects, it is of fundamental importance to be aware of this phenomenon.

According to Shao et al. (2010), most of the studies on the mechanical properties of bamboo are performed in the culm sections without node, even though it is known that the nodes have an influence on the mechanical strength. In the specific case of the tensile strength parallel to the fibers, the node reduces the mechanical strength (Beraldo 2003, Shao et al. 2010), what may be explained by the fact that, at the node, fibers generate transverse stresses (Beraldo 2003), due to the discontinuities of the fibers when they connect at the nodes (Shao et al. 2010).

Thermal treatments can be used to reduce the moisture content of bamboo culms, or even to modify their mechanical resistance (Beraldo 2003). As stated by Esteves \& Pereira (2009), the oven treatments for wood are commonly carried out at temperatures between $160{ }^{\circ} \mathrm{C}$ and $260^{\circ} \mathrm{C}$, and the best conditions of oven treatment against the Coriolus versicolor fungus are obtained with a temperature varying between $200{ }^{\circ} \mathrm{C}$ and $220^{\circ} \mathrm{C}$, in periods between $1 \mathrm{~h}$ and $2 \mathrm{~h}$.

For Phyllostachys pubescens, between $120^{\circ} \mathrm{C}$ and $180{ }^{\circ} \mathrm{C}$, there is an increase in the elasticity modulus and reduction in the flexural strength (Yun et al. 2016). According to the virgin coconut oil treatment carried out by Manalo \& Acda (2009), the water absorption and fracture point are reduced when the bamboo culms are treated at $200{ }^{\circ} \mathrm{C}$, instead of $160{ }^{\circ} \mathrm{C}$, and there are no differences on treatments of $30 \mathrm{~min}$ and $60 \mathrm{~min}$. According to Ochi et al. (2002), the oven treatments at atmospheric pressure were the least damaging to the tensile strength parallel to the fibers, and the treatment temperatures between $140{ }^{\circ} \mathrm{C}$ and $160{ }^{\circ} \mathrm{C}$ did not significantly modify the tensile strength parallel to the fibers, as well as there was no difference in the treatment period between $0.5 \mathrm{~h}$ and 
2 h. Kim et al. (2001) stated that, for temperatures between $300{ }^{\circ} \mathrm{C}$ and $340{ }^{\circ} \mathrm{C}$, a degradation was verified in crystalline regions. Therefore, these zones should be avoided.

Phyllostachys aurea is most used in Brazil for its applications on furniture, possibly due to its resistance and easiness to fold when heated (Oliveira et al. 2010), while $P$. pubescens has the necessary dimensions for many civil construction applications in India (Sakaray et al. 2012). Native to the southeast Asia, Dendrocalamus asper is one of the most used species in Malaysia (Shah et al. 2016).

This study aimed to evaluate the influence of the internal moisture content and of the node presence on the tensile strength parallel to the fibers of D. asper, P. pubescens and $P$. aurea culms. These species were selected because they have different sizes and are commonly used in structural projects. Via descriptive analysis, the influence of the moisture content on the dimensional variation and water absorption were also verified.

\section{MATERIAL AND METHODS}

The experiment was carried out at the Universidade de Itaúna, in Itaúna, Minas Gerais state, Brazil. The bamboo culms were acquired and received in August 2016. In the first half of September 2016, the tested specimens were prepared and the adjustments for the test were made. The tests were performed between the second half of September 2016 and the first half of October 2016.

Density was calculated from the ratio between mass (Marte scale, $0.01 \mathrm{~g}$ precision, model AD2000) and volume $(20 \mathrm{~mL}$ glass volumetric tube, $0.1 \mathrm{~mL}$ precision).

To consider the properties variation for the bamboo species, three species of different sizes were selected (Table 1).

These bamboos were obtained from a Brazilian company specialized in the production and commercialization of bamboo for structural applications. This has been defined to ensure a better control over important aspects, such as age, harvesting date and height of the used culm sections, which were the lower parts of the bamboo, defined as it follows: up to $5 \mathrm{~m}$ above the ground for $D$. asper, $3 \mathrm{~m}$ for $P$. pubescens and $2 \mathrm{~m}$ for $P$. aurea.

To induce the different moisture contents to the tested specimens, four moisture conditions were established: ambient, saturated, oven dried and control. For the control condition, bamboo culms treated by a Brazilian specialized company were used, from which the sap was removed, and then they were thermally treated using an autoclave and chemically treated with chromate copper arsenate. For the ambient condition, there was no drying, saturation or other treatment, and the specimens were tested without any induced modification into their moisture content. For the saturated condition, the objective was to raise the specimen moisture content, so the specimens were immersed in water for $48 \mathrm{~h}$, then the excess of water was poured by staying under ambient condition for $120 \mathrm{~min}$, and all tests were performed within $40 \mathrm{~min}$. For the oven dried condition (Table 2), a treatment under atmospheric pressure in a muffle furnace (GP Científica, model GP-2000G-M) was carried out. This treatment was selected because it is the least damaging (Ochi et al. 2002). The temperature range was pre-established between $150^{\circ} \mathrm{C}$ and $160^{\circ} \mathrm{C}$. According to Esteves \& Pereira (2009), this temperature range provides a high rate of moisture loss, without reducing the tensile strength parallel to the fibers. The duration of the treatments varied according to the bamboo species, because the wall thickness depends on the bamboo species considered.

The moisture content was obtained by an instrument (Texto, model 606) commonly used in the construction industry, and was evaluated in six test specimens, just before the destructive test was carried out. Their mean values are shown in Table 3.

In order to verify the influence of the moisture content on the dimensional variation and water

Table 1. Specifications of the studied bamboo species.

\begin{tabular}{lccrrrr}
\hline \multirow{2}{*}{ Scientific name } & Age & Distance between nodes & External diameter & Thickness & Density \\
\cline { 2 - 6 } & years & & & 118.91 & 10.40 & $\mathrm{~g} \mathrm{~cm}^{-3}$ \\
\hline Dendrocalamus asper & 7 & 518.8 & 70.03 & 6.73 & 0.54 \\
Phyllostachys pubescens & 7 & 354.1 & 32.73 & 4.15 & 0.78 \\
Phyllostachys aurea & 7 & 196.4 & $\mathrm{~mm}$ & \\
\hline
\end{tabular}


Table 2. Conditions used to reduce the moisture content of the bamboo tested specimens.

\begin{tabular}{lccc}
\hline \multicolumn{1}{c}{ Species } & Duration $(\mathrm{min})$ & Temperature range $\left({ }^{\circ} \mathrm{C}\right)$ & Stabilization time $(\mathrm{min})$ \\
\hline Dendrocalamus asper & 120 & $150-160$ & 120 \\
Phyllostachys pubescens & 70 & $150-160$ & 120 \\
Phyllostachys aurea & 50 & $150-160$ & 120 \\
\hline
\end{tabular}

Table 3. Mean moisture content (\%) for the bamboo species and conditions, with and without node.

\begin{tabular}{lcccccc}
\hline \multirow{2}{*}{ Condition } & \multicolumn{2}{c}{ Dendrocalamus asper } & \multicolumn{2}{c}{ Phyllostachys pubescens } & \multicolumn{2}{c}{ Phyllostachys aurea } \\
\cline { 2 - 7 } & Without node & With node & Without node & With node & Without node & With node \\
\hline Ambient & 18.60 & 17.50 & 15.00 & 14.86 & 15.89 & 15.43 \\
Oven dried & 8.62 & 8.67 & 8.01 & 9.00 & 6.33 & 10.83 \\
Saturated & 38.67 & 32.14 & 30.29 & 35.87 & 25.62 & 22.57 \\
Control & 20.57 & 20.00 & 13.50 & 13.83 & 15.22 & 15.44 \\
\hline
\end{tabular}

absorption, three samples of each studied species were used, manufactured from the same sections of the specimens (Figure 1).

The tested specimens were accompanied by these samples from storage, preparation and treatment, until the destructive test was performed, when the measurements were verified. It was accomplished so that the moisture conditions of the samples were as close as possible to those of the tested specimens; thus, it was expected that they had a similar internal moisture content. Then, a descriptive

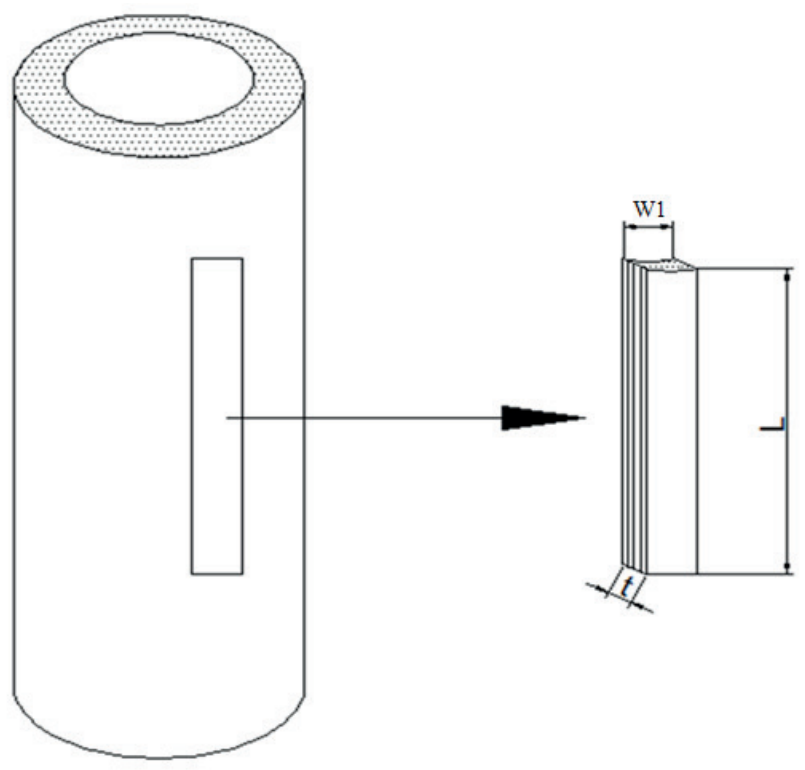

Figure 1. Samples used to verify the effects of the moisture content on the dimensional variation and water absorption of bamboo culms. Width (W1) $=8 \mathrm{~mm}$; length $(\mathrm{L})=100 \mathrm{~mm} ; \mathrm{t}=$ wall thickness of the section. analysis was performed, relating the effect of the moisture content of the specimens on their tensile strength parallel to the fibers and their dimensional variation. The differences were calculated by the following formula:

$$
\mathrm{d}=\frac{\mathrm{X}_{2}-\mathrm{X}_{1}}{\mathrm{X}_{1}} \times 100 \%
$$

where $X$ can be the width, wall thickness, length or density; $X_{1}$ is the variable $X$ considered at time 1 ; and $X_{2}$ is the variable considered at time 2 .

For the descriptive analysis, firstly, for each species, the dimensions (width, wall thickness and length) of three samples were measured at two points, and the mean values of the saturated and oven dried conditions of the six measurements were compared with six measurements of the ambient condition. For analyzing the influence of the moisture content on density, the densities, calculated as previously explained, were compared to the studied conditions.

The tested specimens were prepared according to the Figure $2 \mathrm{a}$, and the dimensions were established according to the bamboo species (Table 4). After several tests, the width was defined, because the efforts of the tensile test grips caused shear forces which tended to crack the material longitudinally, due to the curvature of the extreme areas of the tested specimens. The length of the tested specimens manufactured with $P$. aurea was restricted by the length of the culms. The thickness varies even for different parts at the same section between the nodes. Figure $2 \mathrm{~b}$ presents examples of the tested specimens. 
Table 4. General dimensions ( $\mathrm{W}=$ width; $\mathrm{L}=$ length) of the tested specimens.

\begin{tabular}{lccccc}
\hline \multicolumn{1}{c}{ Species } & W $(\mathrm{mm})$ & W1 $(\mathrm{mm})$ & L $(\mathrm{mm})$ & L1 $(\mathrm{mm})$ & L2 $(\mathrm{mm})$ \\
\hline Dendrocalamus asper & $\sim 20$ & $\sim 10$ & $\sim 200$ & $\sim 60$ & $\sim 70$ \\
Phyllostachys pubescens & $\sim 16$ & $\sim 8$ & $\sim 180$ & $\sim 60$ & $\sim 60$ \\
Phyllostachys aurea & $\sim 12$ & $\sim 6$ & $\sim 160$ & $\sim 60$ & $\sim 50$ \\
\hline
\end{tabular}

A universal EMIC test machine (model DL20000) from the metallography laboratory of the Universidade de Itaúna was used for the tensile tests.

According to Hibbeler (2010), the tensile strength is calculated as it follows:

$$
\sigma_{\mathrm{U}}=\frac{\mathrm{F}_{\max }}{\operatorname{area}}=\frac{\mathrm{F}_{\max }}{\mathrm{W} 1 \times \mathrm{t}}
$$

where $F_{\text {max }}$ is the maximum force applied to the tested specimen, in Newtons; and $W 1$ and $t$ are the dimensions, in mm, as shown in Figure 2a. The tensions obtained by this formula result in $\mathrm{MPa}$.

A completely randomized design, following a $3 \times 2$ factorial scheme (bamboo species $\mathrm{x}$ node presence or absence), with six replications per treatment, was used. The data were submitted to analysis of variance (Anova). For all experiments, the
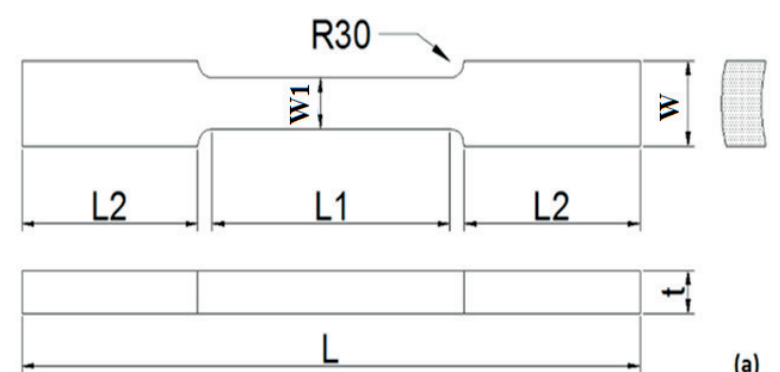

(a)

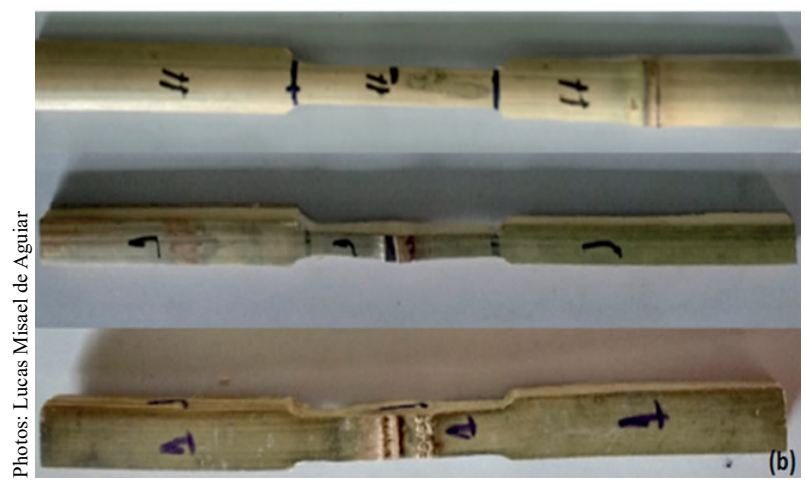

Figure 2. Representation of the tested specimens and their dimensions ( $\mathrm{a} ; \mathrm{W}=$ width; $\mathrm{L}=$ length $\mathrm{t}=$ wall thickness; $\mathrm{R} 30=$ radius of $30 \mathrm{~mm}$ ), with Dendrocalamus asper, Phyllostachys pubescens and Phyllostachys aurea from the bottom to the top (b).
Shapiro-Wilk test was used to verify the normality of the residues, and the Bartlett test to verify the homogeneity of variance. The cases in which the assumptions were met, the Anova was conducted, and, later, the means were compared by the ScottKnott test. All tests were performed considering a $5 \%$ significance level.

All statistical analysis and graph drawings were performed using the statistical software R, version 3.4.2 (R Core Team 2016).

\section{RESULTS AND DISCUSSION}

Tables 5 and 6, respectively, present the mean variation of the dimensions and the densities of the samples used for the established moisture conditions and selected species.

It can be verified that, when compared to the ambient condition, the average values of the oven dried condition show a negative difference for almost all the dimensions observed, i.e., they reduce their dimension. On the other hand, when compared to the ambient condition, the difference for the saturated one presented positive values. It can also be noticed that, apparently, the effect of the dimensions has a smoother effect, when the measurement is taken longitudinally, i.e., along the length of the culm fibers.

On average, the reduction of the internal moisture causes a considerable mass loss, but there is also a reduction in the dimensions, and consequently in the volume. Therefore, as the rise in the moisture content causes a considerable gain in mass, it also increases the culm volume. Hence, the difference in density for the evaluated conditions is not intuitive. For the oven dried condition, D. asper presented a density reduction, what means that, even if there was a reduction in the mean dimensions (width, length and wall thickness), the reduction in the mass was greater. In this condition, the culms of $P$. pubescens and $P$. aurea had increased their density, as well as all the species for the saturated condition, what indicates that there was a greater reduction in the aforementioned dimensions related to the mass loss. 
Table 5. Mean dimensional variations in the sections $(\mathrm{t}=$ wall thickness; $\mathrm{W} 1=$ width; $\mathrm{L}=$ length $)$ of the tested specimens, as a function of the operating conditions studied for the established conditions.

\begin{tabular}{lcrrrrr}
\hline \multirow{2}{*}{ Species } & \multirow{2}{*}{ Dimension } & \multicolumn{5}{c}{ Considered conditions } \\
\cline { 3 - 7 } Dendrocalamus & $\mathrm{t}$ & 12.10 & 11.71 & -3.22 & 13.20 & Difference $(\%)$ \\
asper & $\mathrm{W} 1$ & 7.31 & 7.04 & -3.69 & 7.67 & 4.99 \\
& $\mathrm{~L}$ & 103.48 & 103.94 & 0.44 & 103.88 & 0.39 \\
\hline \multirow{2}{*}{ Phyllostachys } & $\mathrm{t}$ & 6.40 & 5.77 & -9.84 & 6.55 & 2.34 \\
pubescens & $\mathrm{W} 1$ & 7.26 & 6.52 & -10.19 & 7.31 & 0.69 \\
& $\mathrm{~L}$ & 86.42 & 85.92 & -0.58 & 86.45 & 0.03 \\
\hline \multirow{2}{*}{ Phyllostachys } & $\mathrm{t}$ & 4.44 & 3.86 & -13.06 & 4.52 & 1.80 \\
aurea & $\mathrm{W} 1$ & 6.54 & 6.02 & -7.95 & 6.77 & 3.52 \\
& $\mathrm{~L}$ & 105.60 & 104.97 & -0.60 & 105.62 & 0.02 \\
\hline
\end{tabular}

Table 6. Mean density variations of the tested specimens for the established moisture conditions.

\begin{tabular}{lccccc}
\hline \multirow{2}{*}{ Species } & \multicolumn{4}{c}{ Established conditions } \\
\cline { 2 - 6 } & Ambient & Oven dried & Difference (\%) & Saturated & Difference (\%) \\
\hline Dendrocalamus asper & 0.55 & 0.53 & -3.64 & 0.80 & 45.45 \\
Phyllostachys pubescens & 0.67 & 0.83 & 23.88 & 0.97 & 44.78 \\
Phyllostachys aurea & 0.66 & 0.75 & 13.64 & 0.82 & 24.24 \\
\hline
\end{tabular}

Figure 3 presents some fractures of the tested specimens with and without node.

The dispersion of the tensile strength values parallel to the fibers of the tested specimens manufactured from culms of the studied bamboo species are expressed in Figure 4.

Table 7 presents the mean comparison of the tensile strength parallel to the fibers of the bamboo species for the studied conditions of sections with and without node.

In general, the specimens manufactured from the $P$. pubescens culm presented a greater tensile strength parallel to the fibers, when compared to the other species. That may be explained by its higher density (Ghavami 2005, Shao et al. 2010). Sakaray et al. (2012) verified an average tensile strength for

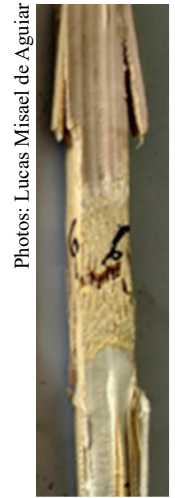

(a)

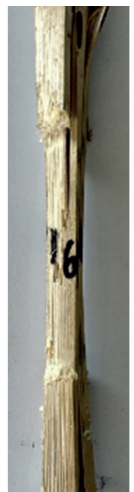

(b)

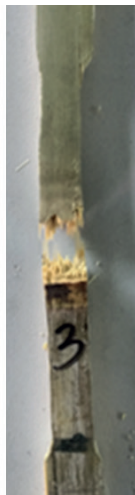

(c)

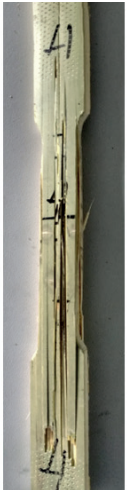

(d)

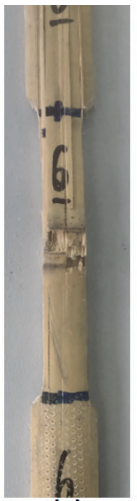

(e)

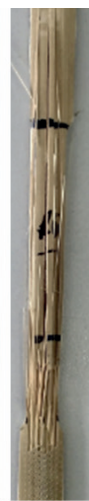

(f)
Figure 3. Fractures observed in the tested specimens from culms of Dendrocalamus asper with (a) and without node (b), Phyllostachys pubescens with (c) and without node (d), and Phyllostachys aurea with (e) and without node (d).

Table 7. Statistical mean comparison of the tensile strength parallel to the fibers (MPa), within each moisture condition studied, on the node presence or absence, and for the three studied bamboo species (PA: Phyllostachys aurea; PP: Phyllostachys pubescens; DA: Dendrocalamus asper).

\begin{tabular}{lccrrrr}
\hline & & Ambient & & \multicolumn{2}{c}{ Saturated in water } \\
\hline & PA & PP & DA & PA & PP & DA \\
\hline Without node & $202.03 \mathrm{Aa}^{*}$ & $182.60 \mathrm{Aa}$ & $106.08 \mathrm{Ba}$ & $174.06 \mathrm{Aa}$ & $182.93 \mathrm{Aa}$ & $121.95 \mathrm{Ba}$ \\
With node & $123.69 \mathrm{Ab}$ & $107.01 \mathrm{Ab}$ & $53.62 \mathrm{Bb}$ & $53.31 \mathrm{Bb}$ & $80.78 \mathrm{Ab}$ & $91.70 \mathrm{Ab}$ \\
\hline & & Oven dried & & & Control $^{1}$ & \\
\hline & $\mathrm{PA}$ & $\mathrm{PP}$ & $\mathrm{DA}$ & $\mathrm{PA}$ & $\mathrm{PP}$ & $\mathrm{DA}$ \\
\hline Without node & $167.73 \mathrm{Aa}$ & $179.28 \mathrm{Aa}$ & $84.33 \mathrm{Ba}$ & $185.08 \mathrm{Aa}$ & $170.85 \mathrm{Aa}$ & $113.75 \mathrm{Ba}$ \\
With node & $79.00 \mathrm{Ab}$ & $103.69 \mathrm{Ab}$ & $36.48 \mathrm{Bb}$ & $129.08 \mathrm{Ab}$ & $110.95 \mathrm{Ab}$ & $54.33 \mathrm{Bb}$ \\
\hline
\end{tabular}

* Means followed by distinct lowercase letters in the columns and capital letters in the rows differ from each other by the Scott-Knott test, at a significance level of $5 \% .{ }^{1}$ Treated by a specialized company. 

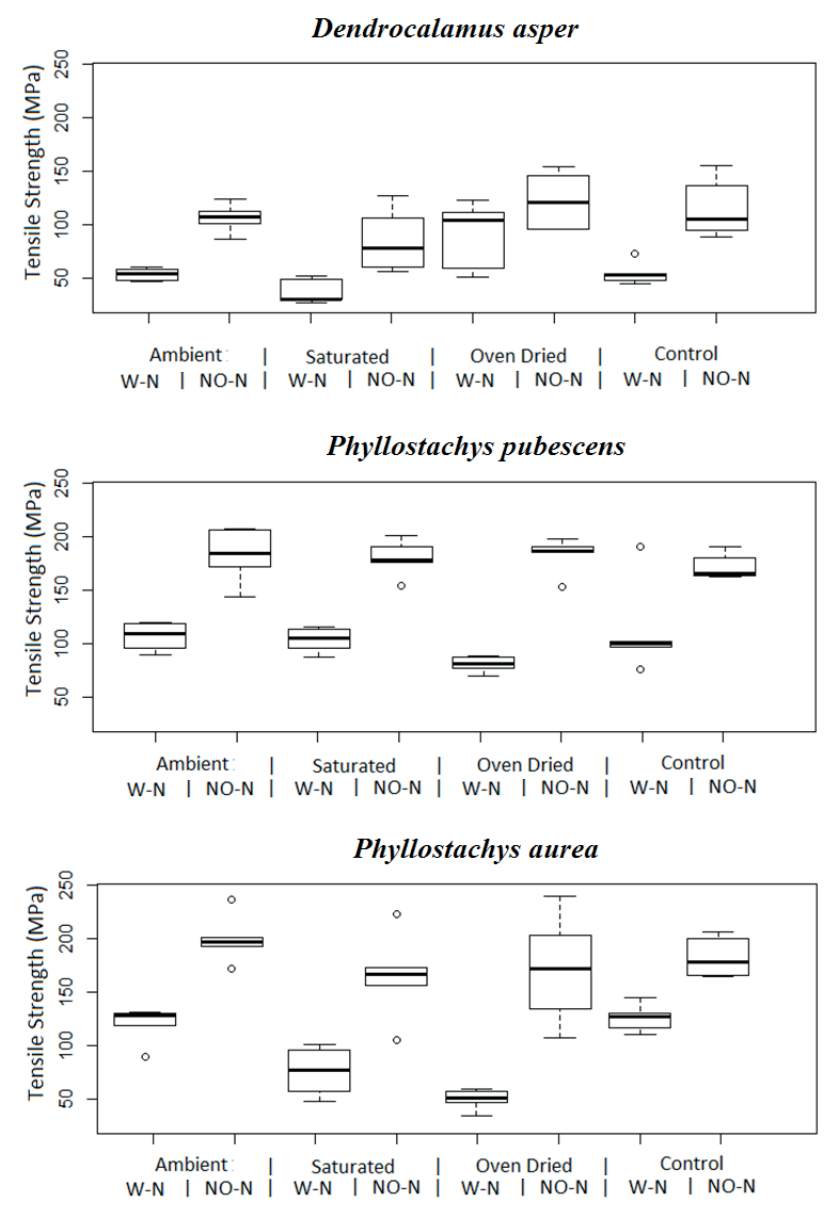

Figure 4. Dispersion of the tensile strength parallel to the fibers for the tested specimens. W-N: with node; NO-N: without node.

tested specimens produced from P. pubescens of approximately $120 \mathrm{MPa}$. According to Oliveira et al. (2010), P. aurea shows a mean tensile strength around $70 \mathrm{MPa}$, while Shah et al. (2016) verified mean values of around $120 \mathrm{MPa}$ for $D$. asper.

For all the studied species and for all moisture conditions, the section with the presence of node weakens the material. Similar results were reported by Beraldo (2003) and Shao et al. (2010). In general, it was verified that the tested specimens produced from the $P$. pubescens culm presented a tensile strength parallel to the fibers statistically equal to $P$. aurea, and significantly different from $D$. asper. Chung \& Yu (2002) state that, for different species, the tensile strength parallel to the fibers varies considerably.

Except for $P$. aurea, in sections with and without node, and $P$. pubescens, in sections with node, it was not observed that a higher moisture content decreased the tensile strength parallel to the fibers, as found by Wakchaure \& Kute (2012) and suggested by Beraldo (2003). One of the main factors responsible for the loss in the strength is the action of insects and fungi (Beraldo 2003, Wakchaure \& Kute 2012). During this study, the tensile test was carried out just after the moisture content had risen, so there was no sufficient time for such damage to interfere in the results. Therefore, the effect of reducing the tensile strength parallel to the fibers related to the high moisture content should be studied for different dwell times under high moisture content conditions.

\section{CONCLUSIONS}

1. For the studied bamboo species (Dendrocalamus asper, Phyllostachys pubescens and Phyllostachys aurea) and for all conditions, it was verified that all the sections with node presented a reduction in the tensile strength;

2. In general, the tested specimens manufactured from the $P$. pubescens culm showed a higher tensile strength than those from $P$. aurea and $D$. asper, what can be explained by its higher density;

3. In almost all conditions, D. asper presented a lower strength than the other species;

4. The bamboo dimensions varied considerably with the variation of the moisture content, presenting an average of more than $10 \%$ in the radial and tangential sections;

5. The mean mass loss was higher than $12 \%$ for the oven dried condition and the average gain was higher than $50 \%$ for the saturated condition. Therefore, in addition to expanding the dimensions, when with a higher moisture content, the water also fills the empty spaces in the bamboo that were once filled by sap;

6 . The high variation on the tensile strength parallel to the fibers, as well as on the dimension and densities for different moisture contents, should be considered for a structural design.

\section{ACKNOWLEDGMENTS}

The authors would like to thank the Coordenação de Aperfeiçoamento de Pessoal de Nível Superior (Capes Brasil - finance code 001) for the scholarship, and the Universidade de Itaúna for the support with instruments for the tests. 


\section{REFERENCES}

BERALDO, A. L. et al. Bambu: características e aplicações. In: FREIRE, W. J.; BERALDO, A. L. Tecnologias e materiais alternativos de construção. Campinas: Ed. Unicamp, 2003. p. 253-295.

CARRASCO, E. V. M. et al. Shear strength of bamboobamboo connection: gluing pressure influence. Matéria, v. 22, n. 1, p. 1-8, 2017.

CHUNG, K. F.; YU, W. K. Mechanical properties of structural bamboo for bamboo scaffoldings. Engineering Structures, v. 24, n. 4, p. 429-442, 2002.

ESTEVES, B. M.; PEREIRA, H. M. Wood modification by heat treatment: a review. BioResources, v. 4, n. 1, p. 370-404, 2009.

GHAVAMI, K. Bamboo as reinforcement in structural concrete elements. Cement \& Concrete Composites, v. 27, n. 6, p. 637-649, 2005.

GHAVAMI, K. Bamboo: low cost and energy saving construction materials. Modern Bamboo Structures, v. 1, n. 1 , p. 5-21, 2008.

GHAVAMI, K. Ultimate load behavior of bambooreinforced lightweight concrete beams. Cement \& Concrete Composites, v. 17, n. 4, p. 281-288, 1995.

HIBBELER, R. C. Resistência dos materiais. New York: Pearson, 2010.

KIM, D. et al. Thermal decomposition of cellulose crystallites in wood. Holzforschung, v. 55, n. 5, p. 521524, 2001.

LIESE, W. The Structure of bamboo in relation to its properties and utilization. In: INTERNATIONAL SYMPOSIUM ON INDUSTRIAL USE OF BAMBOO, 1., 1992, Beijing. Proceedings... Beijing: ISIUB, 1992. p. $95-100$.

MAHZUZ, H. M. A. et al. Determination of several properties of a bamboo of Bangladesh. Journal of Civil Engineering Research, v. 3, n. 1, p. 16-21, 2013.

MANALO, R. D.; ACDA, M. N. Effects of hot oil treatment on physical and mechanical properties of three species of Philippine bamboo. Journal of Tropical Forest Science, v. 21, n. 1, p. 19-24, 2009.

OCHI, S.; TAKAGI, H.; NIKI, R. Mechanical properties of heat-treated natural fibers. Transactions on The Built Environment, v. 59, n. 1, p. 117-125, 2002.

OLIVEIRA, F. H. et al. Use of bamboo culms in bicycle frame construction. In: INTERNATIONAL SYMPOSIUM ON NATURAL POLYMERS AND COMPOSITES, 7., 2010, Araraquara. Proceedings... Araraquara: Ed. Unesp, 2010. p. $1-5$.
R CORE TEAM. $R$ : a language and environment for statistical computing. 2016. Available at: $<\mathrm{http}: / \mathrm{URL}$ https://www.R-project.org/>. Access on: 20 Aug. 2017.

RAPP, A. O.; SAILER, M. Heat treatment of wood in Germany-state of the art. In: SEMINAR ON PRODUCTION OF HEAT TREATED WOOD IN EUROPE, 20., 2000, Berlin. Proceedings... Berlin: Thermo Treated Wood, 2000. p. 1-15.

SAKARAY, H. et al. Investigation on properties of bamboo as reinforcing material in concrete. International Journal of Engineering Research and Applications, v. 2, n. 1, p. 77-83, 2012.

SHAH, A. U. M. et al. A review on the tensile properties of bamboo fiber reinforced polymer composites. BioResources, v. 11, n. 4, p. 10654-10676, 2016.

SHAO, Z. P. et al. Differences in structure and strength between internode and node sections of Moso bamboo. Journal of Tropical Forest Science, v. 22, n. 2, p. 130138, 2010.

WAKCHAURE, M. R.; KUTE, S. Y. Effect of moisture content on physical and mechanical properties of bamboo. Asian Journal of Civil Engineering (Building and Housing), v. 13, n. 6, p. 753-763, 2012.

XU, G. et al. FTIR and XPS analysis of the changes in bamboo chemical structure decayed by white-rot and brown-rot fungi. Applied Surface Science, v. 280, n. 1, p. 799-805, 2013.

YUN, H. et al. Effect of heat treatment on bamboo fiber morphology crystallinity and mechanical properties. Wood Research, v. 61, n. 2, p. 227-234, 2016. 